\title{
THEME SECTION
}

\section{Changing flows in anthropological knowledge}

\author{
Edited by
}

Michał Buchowski and Virginia R. Dominguez 


\title{
Introduction: The politics and ethics of collaboration among World Anthropologies
}

\author{
Michele Hanks
}

The articles in this theme section are based on papers presented at a three-session workshop on World Anthropologies at the 2008 Biennial Conference of the European Association of Social Anthropologists in Ljubljana, Slovenia. Drawing on analyses of the position of anthropological disciplinary practices in Poland, Spain, Hungary, and the US, as well as their global reception, these articles ask important and timely questions about where anthropologists conduct their research, what professional and academic societies they join, what types of relationships they should forge with scholars who live in the country or nation in which they conduct fieldwork, and how they should engage with other disciplines beyond anthropology. As these articles demonstrate, practices of collaboration are enmeshed in politically, socially, and geographically grounded histories. Although at some level this may not be a surprise to readers, specific issues remain well worth examining further and discussing within the profession.

The contributors to this special section of Focaal, for example, seek to imagine the dynamics of more equitable exchanges among anthropologists, anthropological associations, and national traditions in the global political economy of anthropology. How they do so is as important here as why they do so. If Eduardo Restrepo and Arturo Escobar are right that paying attention to world anthropologies involves "a critical awareness of both the larger epistemic and political field in which anthropology emerged and continues to function, and of the micro-practices and relations of power within and across different anthropological locations and traditions" (2005: 100), then we need to delve more deeply into the micro-practices and relations of power among us and not just the broad strokes. The articles here make a point of examining problems and inequalities in the circulation, reception, and interchange between national traditions of anthropology. Each author strives for what Virginia R. Dominguez (this volume) calls "an ethics and politics of professional equality and respect." Each article also raises important questions for anthropologists about the ways we relate to our colleagues at home, abroad, in the field, and across disciplinary boundaries hinting at curative prescriptions for a more equitable exchange among anthropologies. Their analyses are illuminating and, in and of themselves, probably also provocative; their efforts to identify strategies to get us beyond diagnosis or critique may be even more provocative.

\section{Discounting particular national traditions of anthropology}

Readers of Focaal may well be conversant with some related scholarly literature, so I just want to highlight specific issues that come to the fore in this special section of Focaal. Over the years we have seen scholars arguing that anthropo- 
logical scholarship has been valued and interpreted differently in the profession according to a variety of factors. Ruth Behar and Deborah Gordon (1996) and Catherine Lutz (1990) argued this with respect to gender in US anthropology, and Ira Harrison and Faye Harrison (1999) and Louise Lamphere (2004) did much the same for race in US anthropology.

On a far more global level, however, scholars have worried for at least thirty years about the impact of the typical privileging of some national traditions of anthropology over others (Gerholm and Hannerz 1982; Hannerz 2010; L'Estoile, Neiburg, and Sigaud 2005). Sometimes we spot the problem, describe it, and analyze it. Every so often we try to explain it. Dorle Dracklé, Iain Edgar, and Thomas Schippers did a bit of both, noting that "bureaucratic structures, a colonial past, and an economic present" (2003: 2) have much to do with determining the character of national traditions of anthropology in Europe and throughout the world. But part of the question is, or ought to be, whether we can do more about the problem beyond noting the inequalities.

As the articles in this theme section demonstrate, structural inequalities remain in international exchanges among anthropologists. Indeed they are still palpable. To grapple with such interconnections requires that we pay attention to the histories of particular national genealogies of anthropology. Some recent work takes us far. I especially want to note Dorle Dracklé, Iain Edgar, and Thomas Schippers's excellent edited volume titled Educational histories of European social anthropology (2003) and Dorle Dracklé and Iain Edgar's Current policies and practices in European social anthropology education (2004). They both do much to illuminate the disciplinary histories of social anthropology throughout Europe. Likewise, Jan van Bremen and Eyal Ben-Ari's 2005 volume, Asian anthropology, and Shinji Yamashita, Joseph Bosco, and Jeremy Seymour Eades's collection, The Making of Anthropology in East and Southeast Asia (2004), both engage in similar projects by chronicling the histories of Asian anthropologies. It is hard to read those works and not see that serious inequalities remain in the production and circulation of anthropological knowledge.

The contributors to this issue expand on such work by foregrounding and examining the inequalities that exist between particular national traditions of anthropology. Indeed, this collection of articles specifically foregrounds the ways in which scholars working in disciplinary centers such as the US or the UK arguably discount the contributions of anthropologists in disciplinary settings that are not typically seen as primary centers of anthropological theory or knowledge.

As Buchowski, Dominguez, Guarné, and Hann argue here, we continue to live in an anthropological world of continuing tacit or explicit inequalities. Practices of citation, disciplinary formation, and structure warrant close examination. Some of the articles included here explicitly argue that these are grounded in particular geographies, international and domestic politics, and histories that curtail and enable the reach of particular national traditions. The bigger picture should draw our attention but the close-ups may be even more eye-opening and provocative. Buchowski, for example, argues that Western (European and North American) conceptualizations of socialism, post-socialism, and Eastern Europe generally lead to very particular (and unequal) practices of collaboration and engagement. Similarly, Guarné points to specific interconnections between geopolitical imaginaries of the Mediterranean and the ways in which the voices of scholars from the region are discounted. The continuing marginalization within the profession seems as harmful for anthropologists writing from these sites-frequently thought of as peripheries-as they are for anthropologists at the presumably disciplinary centers. Of course, the lingering question remains whether anything can be done about it.

Dominguez, now the immediate past president of the American Anthropological Association (AAA) proposed ways to destabilize the dominance of the association and US anthropology. She suggests that anthropologists working elsewhere should consider hyper-valuing 
US anthropology less and, in turn, US anthropologists should increasingly read, cite, and teach the work of their colleagues outside the US, including outside the north Atlantic region whose anthropological communities have better-known histories in the US. The message may be as unexpected as the messenger here.

\section{Exchanges between sites of anthropological production and activity: "Centers" and "peripheries" and their framing}

Readers will note that the language of world systems theory, with its concern for centers and peripheries, permeates several of the articles in the theme section. These articles ask how the centers of anthropology, including the UK and the US, and the peripheries, including Eastern Europe, should relate to each other. Hann, Buchowski, and Guarné clearly find this a useful formulation and it is one worth pondering, even if it is not one's usual frame of analysis. Each one writes about the marginalized position of socio-cultural anthropology and anthropologists in Hungary, Poland, and Spain respectively. Each also notes the normalizing power of anthropology in and from disciplinary centers-power, they argue, to shape the ideals, practices, and international reception of other traditions.

Putting this in a different frame, Fabian shows some skepticism, warning against allowing the language of "center" and "periphery" to blind us too much, especially from seeing the relations of "imperialist expansion" and "global capitalism" that generally underpin relations among national traditions of anthropology. The analytic distancing included here opens the door to a hopefully useful debate among all of us about specific places and more general patterns.

Readers will find the nuances and differences among the articles in this section as useful as the whole. For example, Hann, Buchowski, and Guarné each implicitly critique the disciplinary reach of anthropology in its centers, but Dominguez tackles the responsibility of anthro- pological associations and anthropologists in the centers quite directly by examining the American Anthropological Association. In considering a more equitable balance of power and responsibility among anthropological traditions, she suggests US anthropology needs to increasingly value collaborations with, and scholarship from, other national traditions while other national traditions would do well to begin relativizing the practices of US anthropology, and presumably other centers including the United Kingdom.

\section{Exchanges with scholars at their field sites}

In addition to the variable nature of scholarly exchanges between anthropologists in anthropology's arguable "centers" and their colleagues in anthropology's arguable "peripheries," the articles in this special section of Focaal remind us that anthropologists often fail to consider the scholarship of researchers working in a variety of intellectual traditions at the sites of their fieldwork.

Both Hann and Buchowski argue that foreign anthropologists conducting research in Eastern Europe have a poor track record of seriously engaging scholarship in Hungary and Poland, especially in fields related to social and cultural anthropology that may be otherwise suspect in their eyes. Most significantly, they raise questions about outsiders' views of ethnology in Poland and néprajz in Hungary. They contend that Western anthropologists rarely cite such scholarship or collaborate with its scholars while conducting research in Eastern or Central Europe. If this is true, how are we all to address the issue? Hann and Buchowski clearly see this as a failure within anthropology. They see the omission as all the more striking since foreign anthropologists cite and engage the scholarship of national historians or political dissidents. As someone who does fieldwork in the United Kingdom and not in Eastern Europe, I find the questions these articles raise more broadly useful. Indeed do foreign anthropologists neglect national traditions of ethnog- 
raphy, folklore, or néprajz, and is this symptomatic of a wider dismissal of other traditions not rooted in the north Atlantic?

Hann and Buchowski also point to the fall of the Iron Curtain as a historical turning point in these collaborations, and the specificity they name raises its own issues for all readers. During socialism, according to Hann and $\mathrm{Bu}$ chowski, ethnologists or néprajz scholars often acted as gatekeepers providing needed access and support to foreign anthropologists. Buchowski (this volume) observes that "dialogue between anthropologists and ethnologists has weakened" since the end of socialism. His article suggests that when practical, logistical help is no longer imperative to the viability of their research, non-native anthropologists engage with national/local anthropological less, no longer needing to cite them, engage with them, or collaborate with them to a great extent. Indeed, Buchowski ties such failures to disciplinary practices he dubs "Categorical Orientalism": arguing that Western anthropologists will only contend with ethnography or scholarship from the peripheries if it conforms to the standards of anthropological disciplinarity as defined by the traditional centers of anthropology in sites such as the United Kingdom or the United States.

In such a provocation, Buchowski encourages readers of all nations and locations to consider the value (or potential value) of a native anthropologist's analysis of his or her own society. Indeed, he calls on us to consider seriously whether national anthropologists may have some "special" insights about their own societies that they can offer foreign anthropologists specifically and anthropology in general. While traditions of "anthropology at home" have increased in recent years (Jackson 1986; Marcus and Fischer 1986; Rapport 2002), Buchowski contends that such scholarship, when produced by Eastern European anthropologists, remains undervalued, particularly by those in position of authority at the metropolitan centers of anthropology. Here, again, the question of an anthropologist's location comes to matter greatly. While Eastern European "anthropology at home" is likely to be seen as parochial at best or contributing to nationalist agendas as worst, there are thriving practices of anthropology at home elsewhere, namely in the US and UK.

I am left wondering about the viability of "anthropology at home." These articles should compel us to ask whether its viability depends on where home is. Curiously, the anthropologies of the US and the UK are written largely by national anthropologists, a practice Dominguez argues must change if we are to establish more amicable exchanges among national traditions of anthropology.

Clearly then these differential practices of national anthropology raise important questions. Among them and highlighted here explicitly or implicitly are the following ones worth pursuing further:

(1) What should the nature of the citation and collaboration be?

(2) Should foreign scholars read such texts with an ethnographic eye?

(3) How should Western European and North American anthropologists treat these colleagues and texts?

(4) Are "native" anthropologists especially capable of offering insights into their own society?

Fabian (this volume) helpfully reminds us that the "concept of alterity is essential to any theory of knowledge that does not, or cannot, bracket the question of intersubjectivity. If such a position is accepted [does it not follow that] ... anthropologists, no matter whether they study their own societies or others, irrespective of levels of development or degrees of involvement in globalization, face essentially the same epistemological problems"? As these contributions show us, all anthropologists must consider how they relate to anthropologists beyond the confines of their own national traditions. Fostering a politics of shared respect and equality requires all of us to examine our disciplinary practices, ideals, and complicities. It also demands more willingness to contemplate unsavory forms of complicity in our professional midst and more willingness to take risks and 
contemplate unconventional suggestions, including some included in this special section.

Michele Hanks completed her PhD in anthropology at the University of Illinois at UrbanaChampaign. Her research interests include science and expertise in the North Atlantic world and the history of anthropology.

Email: michele.hanks@gmail.com.

\section{References}

Behar, Ruth, and Deborah Gordon, eds. 1996. Women writing culture. Berkeley: University of California Press.

Dracklé, Dorle, and Iain Edgar, eds. 2004. Current policies and practices in European social anthropology education. EASA Series. New York: Berghahn Books.

Dracklé, Dorle, Iain Edgar, Thomas Schippers, eds. 2003. Educational histories of European social anthropology. EASA Series. New York: Berghahn Books.

Gerholm, Thomas, and Ulf Hannerz 1982. Introduction: The shaping of national anthropologies. Ethnos 47(1): 1-35.

Hannerz, Ulf. 2010. Anthropology's world: Life in a twenty-first century discipline. New York: Pluto Press.
Harrison, Ira E., and Faye V. Harrison, eds. 1999. African American pioneers in anthropology. Urbana: University of Illinois Press.

Jackson, Anthony, ed. 1986. Anthropology at home. London: Tavistock.

Lamphere, Louise. 2004. Unofficial histories: A vision of anthropology from the margins. American Anthropologist 106(1): 126-139.

L'Estoile, Benoit de, Frederico Neiburg, and Lygia Sigaud, eds. 2005. Empires, nations, and natives: Anthropology and state-making. Durham: Duke University Press.

Lutz, Catherine. 1990. The erasure of women's writing in sociocultural anthropology. American Ethnologist 17 (4): 611-627.

Marcus, George E. and Michael M.J. Fischer. 1986. Anthropology as cultural critique. Chicago: University of Chicago Press.

Rapport, Nigel, ed. 2002. British subjects: an anthropology of Britain. Oxford: Berg.

Restrepo, Eduardo, and Arturo Escobar. 2005. "Other anthropologies and anthropology otherwise": Steps to a world anthropologies framework. Critique of Anthropology 25(2): 99-129.

Van Bremen, Jan, and Eyal Ben-Ari, eds. 2005. Asian anthropology. New York: Routledge.

Yamashita, Shinji, Joseph Bosco, and Jeremy Seymour Eades, eds. 2004. The Making of Anthropology in East and Southeast Asia. New York: Bergham Books. 